\title{
Development of Flipped Learning Based on Android for Elementary School
}

\author{
Yulian Findawati ${ }^{1, \text { a) }}$, Ida Rindaningsih ${ }^{2}$, Wiwik Dwi Hastuti ${ }^{3}$ \\ ${ }^{1,2}$ Universitas Muhammadiyah Sidoarjo, ${ }^{3}$ Universitas Negeri Malang \\ a) Corresponding author: yulian@umsida.ac.id
}

\begin{abstract}
Need of information technology today in education is commonplace, one of which is distance learning. The Reverse Learning Method (Reverse Learning) is an emerging form of blended learning, where learning is carried out online before students enter the classroom and then engage in classroom learning activities tailored to their peers and instructors. While the FL framework will be intuitively attractive, its design and implementation involve considerable complexity. The aim of this study is to develop an FL design model for primary schools that can systematically guide instructors or designers in creating the right mix of individual online lectures and collaborative face-to-face learning activities. By using predetermined methods for model development research, the initial model was theoretically constructed repeatedly and underwent internal and external validation through model use tests. Making learning devices that contain features for students, namely syllabus, learning materials, e-books, games, video lessons, student worksheets. Besides, there are also features for teachers, namely work syllabus, games, e-books, worksheets and learning videos. Meanwhile, for parents, it is a feature to view assignments and grades.
\end{abstract}

Keywords: transfersome gel, fragrant pandan leaf extract, burns.

\section{INTRODUCTION}

E-Learning is a breakthrough in education that utilizes information technology. Various online learning models have begun to be developed. For example, blended learning, distance learning and flipped learning [1]. Online learning is basically trying to innovate and change the paradigm in learning. Flipped Learning was first designed by Beker in 2000 which then developed rapidly that Flipped recently is the interactive nature of learning both inside and outside the classroom using the latest technology. In a flipped classroom, students must meet regularly in a face-to-face setting, students must have ready access to whatever technology is used to communicate outside of the classroom, and designed classroom learning should include learner-centered tasks completed as part of learning community [2].

Studies and research on flipped learning are still developing. From the research conducted it can be concluded that students' perceptions of the application of flipped learning are positive, students who are given material in the form of videos are better at mastery than being asked to read textbooks, students find it difficult to complete the task of reading material and students prefer short videos rather than too long [3]. A study by Moravec et al [4] on biology lectures was carried out through providing narrative power point videos before the lecture took place. This has succeeded in increasing student learning outcomes by $21 \%$ in mastering the concepts in the video. Meanwhile, a study by Roach [5] on microeconomics lectures states that flipped learning 
generates positive responses from students and learning designs that are designed to benefit students.

The results of this study illustrate that flipped learning provides positive updates for learning development. On the other hand, the development of learning that stimulates the ability to master learning materials can also be developed with a research-based learning model [6]. Fulton in Herreid states several advantages of using flipped learning. These advantages are: 1) students can develop according to their respective speed, 2) doing exercises that are usually homework in the classroom gives a better picture to educators about learning styles as well as student learning difficulties, 3) face-to-face time can be used more effective and creative, 4) teachers can more easily assess student achievement, interest and commitment to learning, 5) the use of technology makes learning more flexible and suitable for learning in the 21 st century.

In this study, a fliiped learning device was developed which contains features for students, namely assignments, syllabus, learning materials, e-books, games, video lessons, besides that there are also features for teachers, namely managing classes, managing syllabus, managing games, managing e-books., manage learning videos and manage grades. This application students are expected to be ready and understand the material to be studied before entering class by giving assignments, summarizing the material and subject matter given that must be studied before entering class. With the Android-based flipped learning application, it is hoped that classroom learning for students can run effectively and creatively.

\section{RESEARCH METHODOLOGY}

The type of research used is the type of research and development (Research and Development), which is a research method used to produce certain products and test the effectiveness of these products. This research procedure adapted the ADDIE development model, which is a development model consisting of five stages consisting of Analysis, Design, Development, Implementation and Evaluating.

\section{RESULT AND DISCUSSION}

\subsection{Use Case Diagram Design}

The use case diagram is a description or representation of the interactions that occur between the system and its environment. Use cases are software requirements discovery techniques

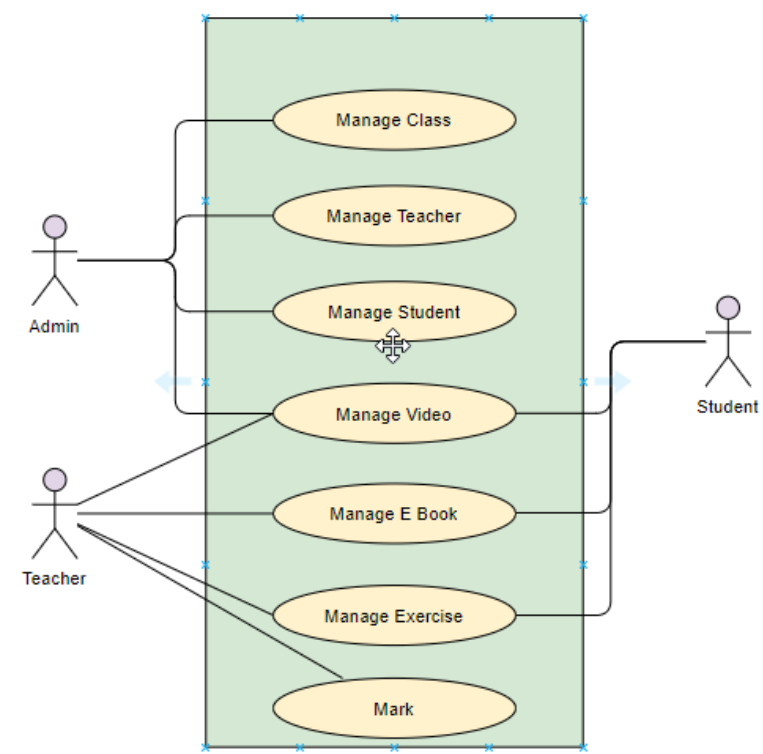

Fig 1. Use Case Diagram Design

The flipped learning is used by 3 users, namely teachers, students, and admin. Where the teacher has access rights to manage the classroom, update teacher identity data, manage students, manage video lessons, manage e-books, manage assignments and conduct assessments. Meanwhile, students can view learning video material, view e-books, and do assignments and get exercise before enter class. 


\subsection{Software Result}

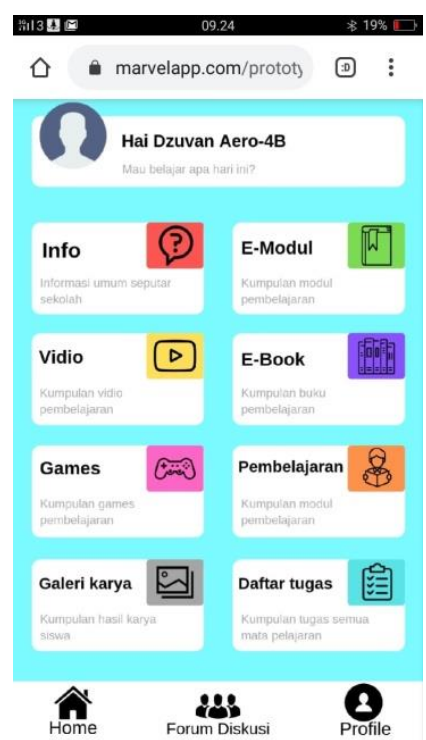

Fig 2. Home

In Figure 1 and Figure 2 are the menus for students where Figure 1 is the main menu for students to choose

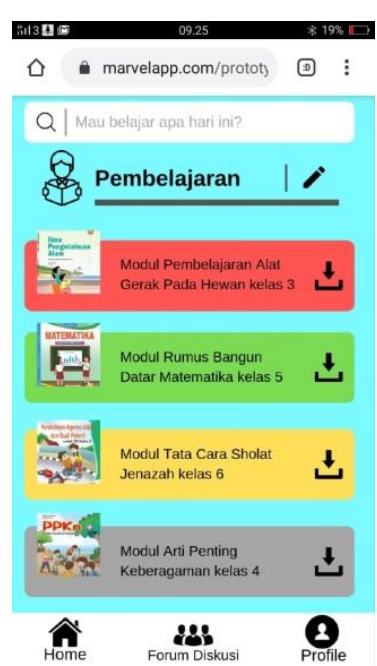

Fig 4. Menu e-Modul

Figure 3 and Figure 4 are the menus for students where Figure 3 is the e-module menu for students to choose the e-module learning media, while in Figure 4 is the assignment link menu for students

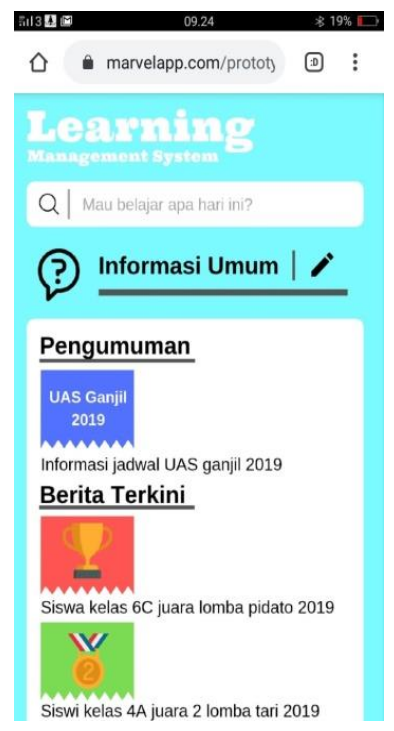

Fig 3. News Menu

learning media according to the learning environment that is suitable for these students

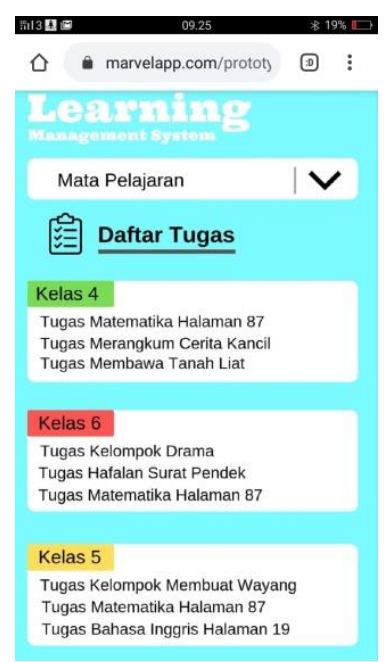

Fig 5. menu tugas 


\section{CONCLUSIONS}

Based on the research that has been done regarding Android-based flipped learning, it can be concluded that:

1. Produced Android-based flipped learning media products as a supporting medium for the reverse learning environment;

2. The product design test results are declared feasible and can be used as a supporting medium for an inverted learning environment

\section{REFERENCES}

[1] P. McKnight, N. Hamdan, K. McKnight, and K. M. Arfstrom, A review of flipped learning. 2013.

[2] J. Bergmann and A. Sams, Flip your classroom: Reach every student in every class every day.
Eugene, OR: International Society for Technology in Education, 2012.

[3] J. L. Bishop and M. A. Verleger, "The Flipped Classroom: A Survey of the Research," 120th Am. Soc. Eng. Educ. Annu. Conf. Expo., vol. 30, pp. 118, 2013.

[4] Moravec, . "Learn before lecture: A strategy that improves learning outcomes in a large introductory biology class," CBE Life Sci Educ, 2010.

[5] T. Roach, "Student perceptions toward flipped learning: New methods to increase interaction and active learning in economics," Int. Rev. Econ. Educ., vol. 17, no. al, pp. 74-84, 2014.

[6] Yulhendri, "Flipped Learning Berbasis Web Pada Pembelajaran Di Universitas Negeri Padang," $J$. Inov. Pendidik. Ekon. JIPE, vol. 8, no. 1, pp. 56-59, 2018. 